\section{Progressive multifocal \\ leukoencephalopathy with selective involvement of the pyramidal tracts}

Alexander Semmler, MD; Horst Urbach, MD, PhD; Thomas Klockgether, MD, PhD; and Michael Linnebank, MD, Bonn, Germany

A 67-year-old man with chronic lymphatic leukemia presented with a 1-month history of subacute right hemiparesis with right central facial palsy and right extensor plantar response, but without sensory deficits. MRI showed hyperintense lesions along the pyramidal tracts on T2-weighted and FLAIR images (figure). CSF PCR revealed JC virus infection leading to the diagnosis multifocal leukoencephalopathy (PML), which typically occurs in immunocompromised patients, due to reactivation of latent JC virus infection. PML lesions are hyperintense on T2-weighted and FLAIR MRI, nonenhancing, not space occupying, and predominantly subcortically located involving the arcuate (U) fibers. Posterior fossa and basal ganglia lesions are less frequent (15 to $30 \%$ of patients) and rarely occur isolated. A faint, peripheral enhancement is seen in up to $10 \%$ of patients. ${ }^{1}$

Thus far, PML with a predominant involvement of the pyramidal tract has been described only in one (HIV-positive) patient. ${ }^{2}$

1. Whiteman ML, Post MJ, Berger JR, Tate LG, Bell MD, Limonte LP. Progressive multifocal leukoencephalopathy in $47 \mathrm{HIV}$-seropositive patients: neuroimaging with clinical and pathologic correlation. Radiology 1993; $187: 233-240$.

2. Sobha N, Sinha S, Taly AB, et al. Progressive multifocal leucoencephalopathy with discrete involvement of pyramidal tract. J Neurol Neurosurg Psychiatry 2005;76:24

Disclosure: The authors report no conflicts of interest.

Address correspondence and reprint requests to Dr. Michael Linnebank, University Hospital Bonn, Dept. of Neurology, Sigmund-Freud-Str. 25, 53105 Bonn, Germany; e-mail: Michael.Linnebank@ukb.uni-bonn.de

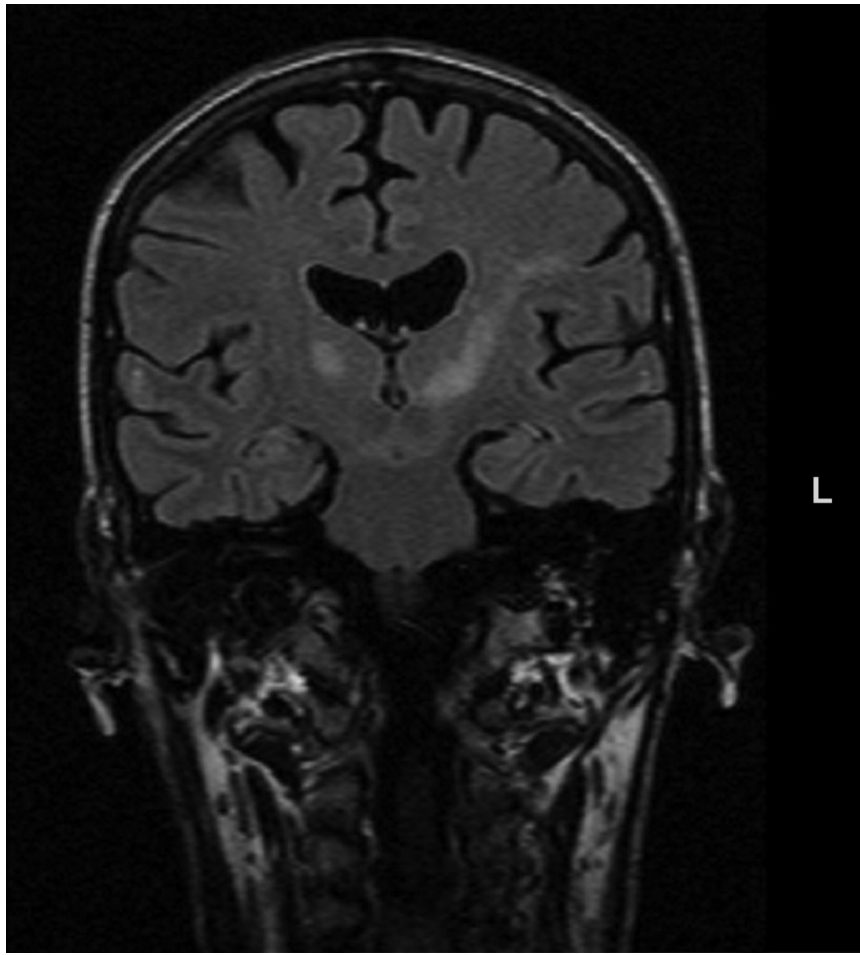

Figure. Coronal FLAIR fast spin echo sequence shows hyperintense lesions along the pyramidal tracts with a predominant involvement of the left side corresponding with the clinical picture. 


\section{Neurology}

\section{Progressive multifocal leukoencephalopathy with selective involvement of the pyramidal tracts}

Alexander Semmler, Horst Urbach, Thomas Klockgether, et al. Neurology 2007;68;871

DOI 10.1212/01.wnl.0000257132.24299.76

\section{This information is current as of March 12, 2007}

\section{Updated Information \&} Services

References

Subspecialty Collections

Permissions \& Licensing

Reprints including high resolution figures, can be found at: http://n.neurology.org/content/68/11/871.full

This article cites 2 articles, 1 of which you can access for free at: http://n.neurology.org/content/68/11/871.full\#ref-list-1

This article, along with others on similar topics, appears in the following collection(s):

\section{Leukodystrophies}

http://n.neurology.org/cgi/collection/leukodystrophies

MRI

http://n.neurology.org/cgi/collection/mri

Information about reproducing this article in parts (figures,tables) or in its entirety can be found online at:

http://www.neurology.org/about/about_the_journal\#permissions

Information about ordering reprints can be found online:

http://n.neurology.org/subscribers/advertise

Neurology ${ }^{\circledR}$ is the official journal of the American Academy of Neurology. Published continuously since 1951, it is now a weekly with 48 issues per year. Copyright . All rights reserved. Print ISSN: 0028-3878. Online ISSN: 1526-632X.

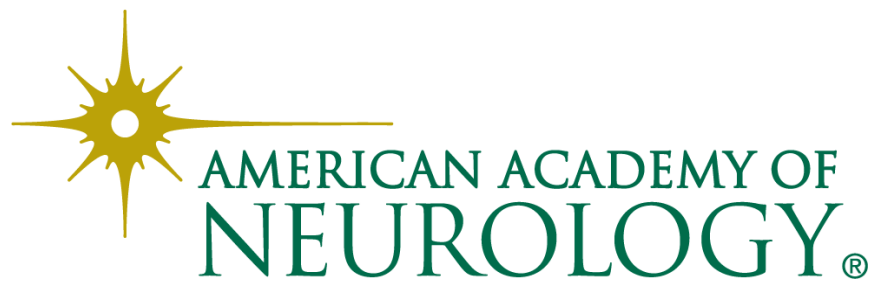

